\title{
SCIENTIFIC AND PRACTICAL COMPONENTS OF TECHNOLOGY OF MILKING ROBOTS ON THE DAIRY COMPLEX AT THE PRIVATE AGRICULTURAL ENTERPISE "VILSHANSKE"
}

\author{
V.I. Lebedynskyi ${ }^{1}$, T.A. Buhay ${ }^{1}$, V.I. Gnoevoy ${ }^{2}$, I.V. Hnoievyi ${ }^{2}$, AK Trishin ${ }^{3}$ \\ ${ }^{1}$ Private agricultural enterprise "Vilshanske", Dvurechansky district, Kharkiv region \\ ${ }^{2}$ Kharkiv State Zooveterenary Academy, Kharkiv, Ukraine \\ ${ }^{3}$ Institute of Animal Science, NAAS
}

Article info

Received 01.03.2019

Received in revised form

04.03.2019

Accepted 18.03.2019

Private agricultural enterprise "Vilshanske",

Dvurechansky district,

Kharkiv region

Myr Str., 89, Vilshanske,

Dvurechansky district,

Kharkiv region, Ukraine,

62732

E-mail: ksp-

vilshana@rambler.ru

Kharkiv State Zooveterenary Academy, Kharkiv, Ukraine Academic Str. 1, Malaya Danilovka, Dergachi district, Kharkov region, Ukraine,

62341

E-mail:

K64.070.02_hdzva@i.ua
Lebedynskyi, V.I., Buhay, T.A., Gnoevoy, V.I., Hnoievyi, I.V., \& Trishin, A.K. (2019). Scientific and practical components of technology of milking robots on the dairy complex at the private agricultural enterpise "Vilshanske". Veterinary science, technologies of animal husbandry and nature management, 3, 183-193. doi: 10.31890/vttp.2019.03.25.

The aim of our scientific research was to determine the period and conditions of the viability of milking robots "Monobox", produced by GEA (Germany) on the dairy complex of the private agricultural enterprise "Vilshanske", Dvurichnaya district, Kharkiv region, Ukraine.

Two robots were brought to the above farm in 2018, each of the robots is able to milk 60 cows/a day by the desire of the cows.

The peculiarities of the scientific investigation were that the efficiency of the use of the milking robots had been determined in the conditions of the solution of the main scientific and practical tasks to create the model welfare conditions for the maintenance of highly producing cows.

It has been found out that in spite of high initial investments the use of the system of a cow milking on a voluntary basis by robots had many advantages, the main of which was the minimization of the human factor, the automatizing of the most important and labor-intensive processes when milking the cows. However, in addition to the effective system of milking the cows' productivity was influenced by some other significant factors, such as: breed selection, qualified selection, economically substantiated fodder basis, the balanced feeding, maintenance in the welfare, for example, the creation of the favorable microclimate, the free movement, free access to the feeds and water, proper veterinary service, etc.

The analysis of the use of robots testified to their good adaptation to the animal needs and the average number of approaches of the cows to the milking robot was 3, 4 times. The quality of milk increased due to the precise doing of the operations as for the fulfillment of the sanitary norms of care about the cow's udder and milking glasses. The milk was separated by 
Institute of Animal Science, NAAS

E-mail: Trishin.ak@ukr.net the milking robots depending on its quality. The robotized system of milk testing and the collection of the data on every quarter of the udder allowed to carry out the analytical treatment and to evaluate the state of the animal, to get the economy of money, first of all, at the expense of the decrease in the manual labor. The viability of the milking robots was 3 years and 10 months.

High scientific and technical level of the economic activity of the milking complex; the scientifically substantiated fodder basis, modern technologies of production, the conservation and the use of feeds, unrestrained maintenance of cows in comfort, all-year-round monotype nutrition of cows by biologically valued

feed mixtures, high quality reproduction of the herd are the basis of the effective use of milking robots.

In the conditions of the milking complex of the private agricultural enterprise "Vilshanske" where the milk yields per year per cow in 2018 were on average $10556 \mathrm{~kg}$ and the profitability of milk production was $34,4 \%$, the viability of the milking robot was 3 years and 10 months.

Key words: cows, milking, manual labor, milking robot, viability.

\title{
НАУЧНЫЕ И ПРАКТИЧЕСКИЕ СОСТАВЛЯЮЩИЕ ТЕХНОЛОГИИ ПРИМЕНЕНИЯ ДОИЛЬНЫХ РОБОТОВ НА МОЛОЧНОМ КОМПЛЕКСЕ ЧСП "ВИЛЬШАНСКОЕ"
}

\author{
В.И. Лебединский ${ }^{1}$, Т.А. Бугай ${ }^{1}$, В.И. Гноевой ${ }^{2}$, И.В. Гноевой ${ }^{2}$, А.К. Тришин ${ }^{3}$ \\ ${ }^{1}$ ЧСП «Вильшанское», Двуречанский район, Харьковская область \\ ${ }^{2}$ Харьковская государственная зооветеринарная академия \\ ${ }^{3}$ Институт животноводства НАAH
}

Целью научных исследований было определение срока и условий окупаемости доильных роботов Мопоbох формы GEA (Германия) в условиях молочного комплекса чСП "Вильшанское" Двуречанского района Харьковской области, Украина.

В 2018 году туда было завезено 2 таких робота, каждый из которых способен выдоить 60 коров/сутки по их желанию.

Особенности научных исследований заключались в том, что эфрфрективность применения доильных роботов определили в условиях решения основных научных и практических задач относительно обеспечения образцового комфортного содержания высокопродуктивных коров.

Было установлено, что, несмотря на высокие начальные инвестиции, использование системы добровольного доения коров роботами дает много преимуществ, основные из которых - минимизация человеческого фрактора, автоматизация наиболее ответственных и трудоемких процессов при доении коров. Однако, на продуктивность коров, кроме эффрективной системы доения, влияет и целый ряд других, не менее важных фракторов: подбор породы, квалифицированная селекция, экономически обоснованная кормовая база, сбалансированное кормление, содержание в комфорте. Например, создание благоприятного микроклимата, обеспечения свободного перемещения, свободного доступа к кормам и воде, своевременная ветеринарная помощь и $\partial p$.

Анализ использования роботов свидетельствует об их четком приспособлении к потребностям животных, а среднее число подходов коров для доения составляло 3,4 раза. Повысилось качество молока за счет четкого выполнения операций по соблюдению санитарных норм ухода за выменем коров и доильными стаканами. Доильный робот разделяет молоко в зависимости от его качества. Роботизированная система тестирования молока и сбор инфрормации по каждой четверти вымени позволяет проводить аналитическую обработку и оценивать состояние 
животных, осуществляется экономия средств, в первую очередь, за счет снижения части ручного труда. Окупаемость доильных роботов составляет 3 года и 10 месяцев.

В основе эфрфективного использования молочных роботов лежит высокий научно-технический уровень хозяйственной деятельности молочного комплекса: научно-обоснованная кормовая база, современные технологии производства, хранения и использования кормов, беспривязное содержание коров в комфорте, круглогодичное однотипное кормление биологически полноценными кормовыми смесями, высококачественное воспроизводство cmada.

В условиях молочного комплекса ПСП "Вильшанское", где в 2018 году среднегодовые надои молока у коров составили, в среднем, 10556 ке, а рентабельность его производства - 34,4\%, окупаемость доильного робота находится в пределах 3 лет и 10 месяцев.

Ключевые слова: коровы, доение, ручной труд, доильный робот, окупаемость.

\title{
НАУКОВІ I ПРАКТИЧНІ СКЛАДОВІ ТЕХНОЛОГІЇ ЗАСТОСУВАННЯ ДОЇЛЬНИХ РОБОТІВ НА МОЛОЧНОМУ КОМПЛЕКСІ ПСП «ВІЛЬШАНСЬКЕ»
}

\author{
В.І. Лебединський ${ }^{1}$, Т.А. Бугай ${ }^{1}$, В.І. Гноєвий ${ }^{2}$, І.В. Гноєвий ${ }^{2}$, О.К. Трішин ${ }^{3}$ \\ ${ }^{1}$ ПСП «Вільшанське», Двурічанський район, Харківська область \\ ${ }^{2}$ Харківська державна зооветеринарна академія \\ ${ }^{3}$ /нститут тваринництва НАAH
}

Застосування молочних роботів забезпечує зменшення застосування ручної праці, покращення умов праці людей та добробуту корів.

Роботизоване доїння корів забезпечує контроль якості молока в реальному часі у кожній чверті вимені корів, що дає можливість підвищити якість молока до преміум класу та суттєво знизити їх захворювання на мастит.

Швидка окупність високих затрат на купівлю, доставку в господарство та монтаж доїльних роботів досягається за умови високої продуктивності корів та високої рентабельності виробництва молока.

В основі ефективного використання молочних роботів лежить високий науково-технічний рівень господарської діяльності молочного комплексу: науково-обгрунтована кормова база, сучасні технології виробництва, збереження і використання кормів, безприв'язне утримання корів у комфорті, цілорічна однотипна годівля біологічно повноцінними кормовими сумішками, високоякісне відтворення стада.

В умовах молочного комплексу ПСП «Вільшанське», де у 2018 році середньорічні надої молока у корів склали, у середньому, 10556 ке, а рентабельність його виробництва - 34,4\%, окупність доїльного роботу знаходиться в межах 3 років і 10 місяців.

Ключові слова: корови, доїння, ручна праця, доїльний робот, окупність.

\section{Вступ}

Метою наукових досліджень було визначення строку і умов окупності доїльних роботів Monobox фрірми GEA (Німеччина) в умовах молочного комплексу ПсП «Вільшанське» Двурічанського району Харківської області, Україна.

В 2018 році туди було завезено 2 таких роботи, кожен з яких здатний видоїти 60 корів на добу за їх бажанням.

Аналіз проблеми в комплексі на прикладі використання технології роботизованого доїння в одному з кращих молочних комплексів України автори вважають однією з актуальних задач на сучасному етапі розвитку молочного скотарства. При цьому ставилися такі задачі:

1. Оволодіти правилами експлуатації доїльного роботу.

2.Визначити наукові і практичні складові технології утримання високопродуктивних корів, що створюють умови для ефективного застосування доїльних роботів.

3. Визначити основні фрактори господарської діяльності молочного комплексу, що сприяють швидкій 
окупності затрат коштів на придбання, доставку, монтаж і обслуговування доїльних роботів.

Об'єкт досліджень - технологічні особливості доїльних роботів в сучасних умовах роботи молочнотоварного комплексу.

Предмет досліджень - реалізація технологічних властивостей доїльних роботів Monobox фрірми GEA (Німеччина) в умовах зразкового добробуту корів, що створений на молочно-товарному комплексі «Вільшанське»

Методи досліджень - науково-господарські, аналітичні, статистичні.

Поява доїльних роботів на нинішній молочній фермі - це технологічна інновація, вихід вітчизняного молочного скотарства на принципово новий рівень.

Особливості наукових досліджень полягали в тому, що ефективність застосування доїльних роботів визначали в умовах вирішення основних наукових $\mathrm{i}$ практичних задач щодо створення зразкового доброту утримання високопродуктивних корів.

Було встановлено, що, не дивлячись на високі початкові інвестиції, використання системи добровільного доїння корів роботами дає багато переваг, основні з яких - мінімізація людського фрактору, автоматизація найбільш відповідальних і трудомістких процесів при доїнні корів. Проте, на продуктивність корів, крім ефективної системи доїння впливає і цілий ряд інших не менш важливих факторів: добір породи, кваліфікована селекція, економічно обґрунтована кормова база, збалансована годівля, утримання в добробуті. Наприклад, створення сприятливого мікроклімату, забезпечення вільного руху, вільного доступу до корму і води, своєчасна ветеринарна допомога та інше.

Аналіз використання роботів свідчить про їх гарне пристосування до потреб тварин, а середня кількість підходів корів для доїння складала 3,4 рази. Підвищується якість молока завдяки чіткому виконанню операцій 3 дотримання санітарних норм догляду за вим'ям корів і доїльними стаканами. Доїльний робот розділяє молоко в залежності від його якості. Роботизована система тестування молока і збір інформації у кожній чверті вимені дозволяє проводити аналітичну обробку і оцінювати стан тварин, відбувається економія коштів, у першу чергу, завдяки зниженню частки ручної праці. Окупність доїльних роботів становить 3 роки і 10 місяців.
Основою ефективного використання молочних роботів $€$ високий науково-технічний рівень господарської діяльності молочного комплексу: науково-обґрунтована кормова база, сучасні технології виробництва, збереження і використання кормів, безприв'язне утримання корів у комфорті, цілорічна однотипна годівля біологічно повноцінними кормовими сумішками, високоякісне відтворення стада.

В умовах молочного комплексу ПСП «Вільшанське», де у 2018 році середньорічні надої молока у корів склали, у середньому, 10556 кг, а рентабельність його виробництва - 34,4\%, окупність доїльного роботу знаходиться в межах 3 років і 10 місяців.

Аналіз останніх досліджень $і$ публікацій. Робота на молочних фермах традиційно вважається важкою, брудною, тому малоавторитетною, особливо серед молоді. Як свідчить досвід господарств, що використовують доїльні роботи, за умови створення повноцінної годівлі і утримання корів, докорінно змінюються умови праці на фермах: зникають важкі фізичні навантаження, покращуються санітарні умови праці для людей та її упорядкованість (Bulyaev, 2016; Kormanovskij, Ivanov, \& Tekuchev, 2008; Sobol', 2008; Legoshhin, Bilkov, \& Anishhenko, 2013). При цьому, економляться кошти та підвищується ефективність бізнесу (Travecz kij, M. Milkua.info. 26.12.2018; ABloud, A.V. https://golos.io/ru. 24.10.2017 Web). Проте, їх впровадження в Україні відбувається значно повільніше, ніж в багатьох інших країнах Європи. Щоб прискорити цей процес необхідно досконало вивчити умови ефективного застосування доїльних роботів, створити сталу, повноцінну кормову базу та утримання корів у добробуті, взагалі забезпечити відповідні умови рентабельного використання робототехніки (Cherny`shova, E. Agro XXI. 11.03.2013 Web. 05.02.2019; Kirsanov, Czoj, \& Kormanovskij, 2016).

Таким чином, поява роботів в Україні - це технологічна інновація, вихід вітчизняного тваринництва на принципово новий рівень. Основною проблемою на шляху подальшого розповсюдження роботизованих систем доїння $€$ висока вартість доїльних роботів - в межах 150-200 тис. євро.

Робот для доїння корів оснащений лазерним сканером, сенсорними датчиками, ультразвуковим пристроєм, оптичною системою, системою контролю якості молока і іншими не менш важливими і складними 
пристроями. Він проводе всі необхідні процедури щодо підготовки вим'я, самостійно приєднує і знімає доїльні стакани, промиває їх. Перші цівки молока робот здоює окремо. Молоко, що поступає із окремої чверті вим'я, тестується на наявність захворювань і лише після цього направляється в охолоджуючий танк. На екрані, що розміщений на одній із панелей роботу, в режимі реального часу з'являються основні характеристики молока (GEA Monobox, G. Gea.com. 12.07.2017; Kirsanov, Pavkin, \& Cimbal, 2015; Taratorkin, Samraxanov, \& Abrashkin, 2017).

Встановлена закономірність між рівномірністю видоювання четвертей вимені і захворюванням маститом. Так, якщо різниця за часом закінчення молоковіддачі із першої і останньої четвертей складає до 0,5 хв., то стійкість до маститу буде більше $80 \%$, до 1 хв. - $60 \%$ і до 2хв. - 30\% (Maklaxov, Abramova, \& Burgomistrova, 2016; Mironova, \& Muromcev, 2013).

За використання молочних роботів захворювання корів на мастит знижується у три рази (Hnoievyi, Buhai, \& Hnoievyi, 2018), а звикання тварин до нового обладнання відбувається, в середньому, 3-4 тижні (Timoshenko, \& Muzy'ka, Belorusskoe sel'skoe xozyajstvo. 26.04.2013).

У порівнянні 3 доїльними роботами попереднього покоління, які вже застосовуються в Україні, Monobox фрірми GEA відзначається більш чітким виконанням усіх необхідних операцій як в підготовчий період, так і за час доїння корів, а відсутність пошкоджень вим'я, його запалень та мікробного осіменіння дає можливість одержати молоко природної якості, тобто на рівні преміум класу. Відомо, що на фермах, де встановлені роботи, є спокійні робочі умови, там досягається самий високий рівень добробуту для корів, що сприяє росту їх продуктивності (Surovcev, V.N., \& Nikulina, Y.N., 2013).

У процесі доїння корів передбачаються такі операції (GEA Monobox, G. Gea.com. 12.07.2017; Maklaxov, Zhil`czov, \& Nikitin, 2017):

- корова заходить в спеціальний відкритий бокс роботу;

- система ідентифікує тварину;

- сенсори визначають розташування корови i передають його на маніпулятор;

- ідеальний догляд за дійками від самого початку: всі етапи доїння у Monobox зосереджені всередині доїльного стакана. Достатньо лише одного під'єднання. Стимуляція дійки починається одразу ж після під'єднання стакана бо вим'я м'яко готується до доїння.

- гігієна і безпека: після під'єднання доїльного стакана починається процес очищення - обробка дійок. Після сушки відбувається процес здоювання перших цівок молока та ідентифікації на мастит тварин. Система датчиків аналізує молоко кожної чверті вим'я на електропровідність, колір, температуру.

- дбайливість та надійність: за час доїння легка підвісна конструкція доїльної рами і доїльного апарата підлаштовується під природні рухи корів та не чинить зайвого тиску на вим'я, а додаткові сенсори вимірюють потік молока з кожної чверті вим'я та об'єм здоєного молока;

- турбота про здоров'я корів: щойно потік молока в одній з чвертей вимені зменшується до певного чергового значення, починається процес обробки відповідної чверті - дезінфікуючий засіб рівномірно та економно розподіляється у всіх складках шкіри дійки та забезпечує надійний захист від збудників маститу.

- одночасне автоматизоване визначення кількості соматичних клітин для визначення якості молока;

- сепарація молока за якістю;

- роздільне зняття доїльних стаканів 3 послідуючим їх пропарюванням та споліскуванням чистою водою;

- обробка вим'я дезінфікуючими розчинами після доїння.

Матеріал $і$ методи досліджень. Наукові дослідження проводились в 2018-2019 роках на молочно-товарному комплексі ПСП «Вільшанське» Двурічанського р-ну, Харківської області, де в 2018 році було встановлено два роботи Monobox фрірми GEA (Німеччина). Один Monobox здатний без участі людини видоювати 60 корів на добу за їх бажанням. Це багатофункціональний маніпулятор нового покоління, який вперше застосовується в Україні.

Особливості роботи полягали в тому, що необхідно було суворо дотримуватись правил експлуатації роботів, а саме: безперебійне забезпечення електроенергією, чистою водою, створення нормальних санітарно-гігієнічних умов в приміщенні.

Модуль доїльного місця в Monobox має працювати 24 години на добу. Кожен етап доїння - 
під'єднання доїльного стакана, стимуляція, очищення, сушка, попереднє здоювання та обробка вимені після доїння - $є$ частиною уніфікованої, швидкої та комфортної для тварин програми, що відбувається за одне під'єднання доїльного апарата окремо для кожної чверті вимені. У літературних джерелах зазначено, що послідовний процес доїння, надійна гігієна та дбайливий захист - це запорука доброго здоров'я корів та високої якості їх молока (GEA Monobox, G. Gea.com. 12.07.2017).

Таблиця 1

Порівняння методів традиційного і роботизованого доїння

\begin{tabular}{|l|c|c|c|}
\hline Показники & $\begin{array}{c}\text { Надій молока на корову, } \\
\text { кг/добу }\end{array}$ & Білок, г/добу & Жир, г/добу \\
\hline Традиційне доїння & 28,5 & 927 & 1241 \\
\hline Молочні роботи & 29,1 & 991 & 1266 \\
\hline Приріст, \% & 2,1 & 6,9 & 2 \\
\hline
\end{tabular}

Дослідження, які проводилися на більш ніж 300 зарубіжних фрермах, показали, що продуктивність зросла, у середньому, лише на 2,1\%, у порівнянні 3 традиційними фермами (GEA Monobox, G. Gea.com. 12.07.2017). На останніх молочна продуктивність підвищилась внаслідок селекції та покращення управління стадом. У цих дослідженнях перші два тижні не враховувались, тому що перехід від традиційної системи до доїння роботами вимагає деякої адаптації тварин, що супроводжувалось зниженням продуктивності корів. Ця різниця значно коливалась на різних фермах. У той час, як один фермер міг досягнути прибавки молока від 10 до 15\%, максимум 17\%, інший, навпаки, міг зменшити продуктивність корів до $6 \%$.

\section{Результати досліджень та їх обговорення}

У перший день випробування роботу корів на молочному комплексі ПСП «Вільшанське» практично «заштовхували» в бокс, але вже на другий-третій день доїння роботом для корів стало звичним явищем, а даванка концентрованих кормів, яку, тварини одержують під час доїння, виявилась настільки смачною, що деякі корови бажали подоїтися до 20 разів за добу. Система ідентифрікації корів такого не дозволяла. У середньому, як свідчить європейський досвід, корови доються 2,7 разів за добу. На молочному комплексі ПСП «Вільшанське» цей показник складає 3,4 рази.

Кожного ранку здійснюється контроль і комп'ютер видає дані про корів, які не доїлися протягом останніх 12 годин. Серед них, зазвичай, були корови, що мали великі надої, а також такі, що дають мало молока. Тому доводилося викопродуктивних корів підганяти до роботу.
Не дивлячись на високі початкові інвестиції, використання систем добровільного доїння роботами дає багато переваг, основні з яких - мінімізація людського фрактору. Доїльні роботи повинні автоматизувати найбільш трудомісткий процес при доїнні корів. Роботи для автоматизованої системи доїння виконують практично всі необхідні при доїнні функції: обробляють вим'я до і після доїння, проводять попереднє доїння, одягають і знімають доїльні стакани, дезінфікують соскову резину, замірюють надій молока і т.і. Доїльні роботи також дають можливість оцінювати стан кожної чверті вимені і своєчасно виявляти ознаки маститу. Ефективність використання роботизованих систем для доїння корів також полягає не тільки у відсутності ручної праці, але і у створенні добробуту для самих тварин. Корові надається свобода вибору терміну і частоти відвідування доїльного боксу, кожна тварина обслуговується у відповідності із своїми добовими ритмами.

Проте, на продуктивність корів, окрім ефективної системи доїння впливає і цілий ряд інших не менш важливих факторів: добір породи, кваліфікована селекція, економічно обґрунтована кормова база, повноцінна збалансована годівля, утримання в добробуті. Наприклад, сприятливий мікроклімат, свобода руху, вільний доступ до корму і води, своєчасна ветеринарна допомога і т.і. Це також необхідно враховувати для ефективного ведення господарювання взагалі, а тим більше в умовах застосування доїльних роботів.

Аналіз використання роботів свідчить, що роботизована система добре пристосована до потреб тварин, і тому середня кількість підходів корів на доїння 
було запрограмовано - 3 рази за добу. Крім цього, відзначали наступне:

1. Підвищується якість молока завдяки чіткому виконанню операцій з дотриманням санітарних норм підготовки вимені тварин.

2. Доїльний робот дає можливість розділяти молоко в залежності від його якості.

3. Роботизована система веде тестування молока і збір інформації у кожній чверті вим'я, що дозволяє проводити аналітичну обробку і оцінювати стан тварин.

4. Економія коштів, у першу чергу, завдяки зниженню частки ручної праці і загальної кількості робітників, що працюють на фермі

5. Відзначається менше травмування тварин та зниження захворювання на мастит.

За умілого підходу до справи у господарстві розраховують на ріст економічної ефективності виробництва молока. Це досягається, наприклад, зростанням надоїв у порівнянні 3 іншими господарствами, у яких використовується традиційна технологія доїння корів. Роботизована доїльна система гарно пристосована до потреб тварин. Як свідчить світовий досвід (Viniczkij, Romanyuk, \& Saviny`x, 2014; Vinniczkij, Romanyuk, \& Yugovar, 2014), на роботизованих фермах відзначається менша кількість тварин, що захворіли на мастит i, взагалі, менший травматизм серед тварин.

Все це відповідає необхідним вимогам збереження і покращення здоров'я стада, забезпечує можливість проводити своєчасну профрілактику стану тварин 3 продовженням строку їх господарського використання. Крім цього, вибракування тварин в господарстві, що оснащене «роботами», значно менше, у порівнянні з нероботизованими фермами. Одержані результати дослідження дають можливість керівникам обґрунтовано підходити до вибору шляхів подальшого розвитку господарств та оцінити свої спроможності при впровадженні роботів-доярів.

Другий суттєвий фрактор підвищення економічної ефрективності - зниження частки ручної праці на фермі і кількості робітників, тому як наслідок зменшення витрат на заробітну плату. Нині 120 корів обслуговують на 5 робітників менше.

Роботизована система доїння корів проводе ряд тестів і веде «досьє» на кожну тварину. Інформація акумулюється в базі даних, а це дає можливість проводити аналітичну обробку. Тести дають змогу відзначити різні захворювання тварин, у тому числі на ранніх стадіях - тварину можна легко виділити зі стада, а її молоко не потрапить в загальну ємність.

Із інших плюсів можна відзначити ріст якості молока, у порівнянні з попередніми роками.

Слід розглядати і негативні сторони застосування доїльних роботів:

1. Висока вартість придбання роботів 3 відповідним підвищенням собівартості продукції, яка може не компенсуватися фондом зарплати, який зменшився після оптимізації кількості робітників молочного комплексу.

2. Підвищення складності доїння, що вимагає спеціалізованого кваліфікованого сервісного обслуговування компанією-виробником.

3. Потреба в стабільному електрообслуговуванні.

4. Як правило, потрібна реконструкція приміщення для монтажу і установки роботів.

5. Підвищення затрат на електроенергію і воду.

6. Відносно низька продуктивність роботів - 6075 корів/на одного робота.

7. Ретельний відбір і добір стада, наприклад, за продуктивністю і здатністю до доїння роботом.

8. Необхідний певний період адаптації корів 3-20 днів.

Аналіз роботи молочного комплексу ПСП «Вільшанське» свідчить, що на ефективність застосування і швидку окупність доїльних роботів впливає жива маса корів.

За новими нормами годівлі високопродуктивних корів (Gnoevoy, Hnoievyi, \& Trishyn, 2008) жива маса корів $є$ визначною щодо рівня споживання ними сухої речовини раціону, що, у свою чергу, зумовлює максимально можливий рівень їх молочної продуктивності. Тобто, чим більша жива маса корови, тим більша ії спроможність споживати суху речовину раціону і більше давати молока. Наприклад, корова з живою масою 500 кг здатна спожити сухої речовини раціону на рівні $5,4 \%$ до своєї живої маси, тобто 27 кг на добу, і мати максимальний надій молока 50 кг/добу. Більшу молочну продуктивність можуть мати корови, жива маса яких складає 600 кг і більше (табл. 2). 
Потреба корів у сухій речовині для підтримання життя, виробництва молока і нормального приросту живої маси в середині і наприкінці лактації, \% до живої маси (Gnoevoy, V.I., Hnoievyi, I.V., \& Trishyn, O.K., 2008)

\begin{tabular}{|c|c|c|c|c|}
\hline \multirow{2}{*}{$\begin{array}{c}\text { Удій молока 4\%-ої } \\
\text { жирнсті }\end{array}$} & 400 & 500 & 600 & 2,00 \\
\cline { 2 - 5 } & 2,7 & 2,4 & 2,2 & 2,0 \\
\hline 10 & 3,2 & 2,8 & 2,6 & 2,6 \\
\hline 15 & 3,6 & 3,2 & 2,9 & 2,9 \\
\hline 20 & 4,0 & 3,5 & 3,2 & 3,2 \\
\hline 25 & 4,4 & 3,9 & 3,5 & 3,4 \\
\hline 30 & 5,0 & 4,2 & 3,7 & 3,6 \\
\hline 35 & 5,5 & 4,6 & 4,0 & 3,8 \\
\hline 40 & - & 5,0 & 4,3 & 4,1 \\
\hline 45 & - & 5,4 & 4,7 & 4,4 \\
\hline 50 & - & - & 5,0 & 4,6 \\
\hline 55 & - & - & 5,4 & \\
\hline 60 & & & \multicolumn{5}{|c|}{ маса, } & \\
\hline
\end{tabular}

Про суттєве значення живої маси корів при застосуванні доїльних роботів свідчать і інші нормативні дані (табл.

3). Оскільки дані таблиць 2 і 3 рідко зустрічаються в довідковій літературі, ми приводиво їх повністю.

Таблиця 3

Мінімально необхідна концентрація обмінної енергії в сухій речовині раціонів корів, МДж/кг

(Gnoevoy, Buhai, \& Hnoievyi, 2018)

\begin{tabular}{|l|c|c|c|c|c|c|c|c|}
\hline \multirow{2}{*}{$\begin{array}{l}\text { Жива маса } \\
\text { кг }\end{array}$} & \multicolumn{7}{|c|}{ Добовий надій молока, ке } \\
\cline { 2 - 9 } & 5 & 10 & 15 & 20 & 25 & 30 & 35 & 40 \\
\hline 400 & 8,0 & 9,5 & 10,8 & 12,0 & 12,4 & 12,9 & - & - \\
\hline 450 & 8,0 & 9,0 & 10,3 & 11,5 & 12,0 & 12,4 & - & - \\
\hline 500 & 8,0 & 8,6 & 9,8 & 10,9 & 11,5 & 11,8 & 12,2 & 12,5 \\
\hline 550 & 8,0 & 8,3 & 9,5 & 10,5 & 11,2 & 11,4 & 11,8 & 12,2 \\
\hline 600 & 8,0 & 8,0 & 9,1 & 10,0 & 10,8 & 11,0 & 11,4 & 11,8 \\
\hline 650 & 8,0 & 8,0 & 8,8 & 9,7 & 10,4 & 10,7 & 11,0 & 11,5 \\
\hline 700 & 8,0 & 8,0 & 8,4 & 9,4 & 10,0 & 10,3 & 10,7 & 11,2 \\
\hline
\end{tabular}

Наведені в таблиці 3 дані свідчать, що зі збільшенням живої маси корів може знижуватись концентрація обмінної енергії в сухій речовині раціону. Для дрібної корови масою 450 кг і за умови її молочної продуктивності в межах 30 кг/добу концентрація обмінної енергії в сухій речовині раціону має бути на рівні 12,4 МДж/кг. Але така поживність характерна для багатьох концентрованих кормів. Навіть у висококонцентратних раціонах допускається вміст концентрованих кормів у межах 50-55\% від загальної енергетичної поживності раціону. Це свідчить про те, що висока потреба дрібних корів у концентрації енергії в раціоні суттєво обмежує верхню межу їх продуктивності, що не сприяє швидкій окупності доїльних роботів. У той же час, у корів з живою масою
650 кг і надоєм молока 30 кг/добу концентрація енергії в сухій речовині раціону складає 10,7 Мдж/кг. Зрозуміло, що високі надої молока, які легко реалізувати у виробничих умовах, характерні для корів з великою живою масою.

У сучасних умовах господарювання, впровадження прогресивних технологій виробництва молока на основі безприв'язного способу утримання корів і добровільної роботизованої системи доїння може забезпечувати підвищення ефективності виробництва молока. Не дивлячись на значну капіталоємність, сучасні технології вирішують задачі зниження затрат і підвищення якості продукції. Розрахунки терміну окупності доїльних роботів на молочно-товарному комплексі ПСП «Вільшанське» наводяться в табл. 4. 
Розрахунок терміну окупності доїльних роботів в ПСП «Вільшанське»

\begin{tabular}{|l|c|}
\hline \multicolumn{1}{|c|}{ Показники } & 2018 рік \\
\hline Кількість корів, гол. & 120 \\
\hline Продуктивність корів, в середньому 1 голови/рік, кг & 10556 \\
\hline Середня жива маса 1 корови, кг & 650,5 \\
\hline Валовий надій, т & 1266,7 \\
\hline Середня ціна реалізації молока, грн. /т & 9156,5 \\
\hline Виручка від реалізації молока, млн. грн. & 11,6 \\
\hline Рентабельність виробництва молока, \% & 34,4 \\
\hline Прибуток, млн. грн. & 3,99 \\
\hline Затрати на придбання та монтаж роботів, млн. грн. & 14,99 \\
\hline Окупність роботів, рік & 3,8 \\
\hline
\end{tabular}

Дані таблиці 4 свідчать, що основними факторами, які зумовлюють термін окупності доїльних роботів, є рівень молочної продуктивності корів і рентабельність виробництва молока в господарстві. У цьому аспекті ПСП «Вільшанське» досягнуло значних успіхів. Зокрема, надої молока у корів перевищили 10 тис. кг/рік за рентабельності його виробництва в межах 34-50\%. При цьому, якість молока відповідає вимогам ДСТУ. Слід зазначити, що застосування доїльних роботів суттєво не впливає на рівень продуктивності корів і якість молока, за винятком санітарно-гігієнічних вимог. За умов використання доїльних роботів якість молока за цим показником досягла рівня преміум-класу.

Високій окупності доїльних роботів сприяло переведення господарства на нові організаційні і технологічні основи господарювання, в тому числі i молочного комплексу. Це стосується як створення науково обґрунтованої системи виробництва кормів на інноваційній основі, так і реконструкція тваринницьких приміщень (Hnoievyi, Buhai, \& Hnoievyi, 2018). Велике значення В цьому аспекті набуло впровадження цілорічно однотипної годівлі тварин з використанням біологічно повноцінних кормових сумішок (Hnoievyi, \& Trishyn, 2007; Gnoevoy, Hnoievyi, \& Trishyn, 2008). Ці та інші заходи дали змогу при умові зменшення поголів'я корів майже на $30 \%$ збільшити валове виробництво молока в 1,4 раза. В міру збільшення обсягів виробництва молока господарство стало більше використовувати кормів, проте витрати їх з розрахунку на 1 ц продукції, навпаки, знизились на 10\%, зменшились також витрати людино-годин у розрахунку на 1 ц виробленого молока.
Bce зазначене дає можливість визначити основні наукові і практичні передумови ефективного застосування доїльних роботів на молочних комплексах.

Перспективи подальших досліджень. Перспективні напрямки подальших досліджень наступні:

Визначення основних фракторів роботи молочних комплексів, що сприяють скороченню термінів окупності доїльних роботів. Це, у першу чергу, стосується підвищення рівня молочної продуктивності корів, підвищення якості (Prudnikov, V.H., Lysenko, H.L., \& Vasylieva, Y.O.,2015 ; Palii, A.P., Nanka, O.V., \& Prudnikov, V.G., 2019; Prudnikov, V.H., Tarasova, T.O., \& Tarasov, M.A., 2011 ; Kamil Al -Bazi, M., Prudnikov, V.G., \& Rudenko, E.V., 2013.), зниження собівартості його виробництва та підвищення рентабельності роботи молочного комплексу в цілому.

\section{Висновки}

1. За умови надоїв молока у корів на рівні 10556 кг на рік і рентабельності його виробництва $34,4 \%$, що характерно для молочно-товарного комплексу ПСП «Вільшанський», окупність доїльних роботів може складатись у межах 3 років і 10 місяців.

2. Висока продуктивність корів та рентабельність його виробництва на молочно-товарному комплексі ПСП «Вільшанський» досягнута завдяки науковообґрунтованої реконструкції тваринницьких приміщень, організації зразкового добробуту тварин при утриманні та доїнні, створенню власної повноцінної кормової бази на основі пріоритетних кормових культур та технології заготівлі, зберігання і використання кормів, організації цілорічно однотипної годівлі корів біологічно 
повноцінними кормовими сумішками, науковій організації праці та якісного ветеринарного забезпечення тварин.

\section{References}

ABloud, A.V. Roboty: Molochnaya ferma bez lyudej? Pochti ne fantastika. https://golos.io/ru. 24.10.2017 Web. 12.02.2019 Retrieved from https://golos.io/ru-robototekhnika/@abloud/roboty-molochnaya-fermabez-lyudei-pochti-ne-fantastika

Bulyaev, N.V. (2016). Principy` raboty` robotizirovannoj sistemy` doeniya korov v SPK «Glinskij». Principy raboty 'robotizirovannoj sistemy` doeniya korov $v$ SPK «Glinskij», 1, 1.

Cherny`shova, E. Robotizirovannaya ferma. Agro XXI. 11.03.2013 Web. 05.02.2019. Retrieved from https://www.agroxxi.ru /zhivotnovodstvo/

tehnologi/robotizirovannaja-ferma.html

GEA Monobox, G. Ideal prospects for milk production. Gea.com. 12.07.2017 Web. 17.01.2019 Retrieved from

https://www.gea.com/en/binaries/1602017 Monobox_LowRes_GB_529862_tcm11-31184.pdf

Gnoevoy, V.I., Buhai, T.A., \& Hnoievyi, I.V. (2018). Dobrobut koriv na molochnykh kompleksakh. Kharkiv: Operatyvna polihrafiia» FOP Zdorovyi Ya.A.

Gnoevoy, V.I., Hnoievyi, I.V., \& Trishyn, O.K. (2008). Hodivlia vysokoproduktyvnykh koriv. Kharkiv: Prapor.

Hnoievyi, I.V., \& Trishyn, O.K. (2007). Systema staloho vyrobnytstva i efektyvnoho vykorystannia kormiv za tsilorichno odnotypnoi hodivli vysokoproduktyvnykh koriv. Kharkiv: Mahda LTD.

Kamil Al'-Bazi, M., Prudnikov, V.G., \& Rudenko, E.V. (2013). Ocenka biologicheskoj polnocennosti belkov moloka. Naukovo-texnichnij byuleten' Institutu tvarinnicztva NAAN, 109, 57-63.

Kirsanov, V.V., Czoj, Y.A., \& Kormanovskij, L.P. (2016). Koncepciya sozdaniya doilnogo robota, sovmestimogo $s$ otechestvenny`m doil’ny`m oborudovaniem. Vestnik Vserossijskogo nauchnoissledovatel'skogo instituta mexanizacii zhivotnovodstva , 3, 13-20.

Kirsanov, V.V., Pavkin, D.Y., \& Cimbal, A.A. (2015). Rezul taty` obrabotki e`ksperimental `ny`x danny`x $s$ robotov doeniya po chetvertyam vy`meni
. Rezul'taty`obrabotki e`ksperimental'ny'x danny`x $s$ robotov doeniya po chetvertyam vy`meni, 4, 122128.

Kormanovskij, L.P., Ivanov, Y.A., \& Tekuchev, I.K. (2008). Tendencii primeneniya doilny`x robotov . Texnika $i$ oborudovanie dlya sela, 8, 36-38.

Legoshhin, G., Bilkov, V., \& Anishhenko, A. (2013). Sravnitel'naya e`ffektivnost` texnologij proizvodstva moloka na fermax $s$ doeniem $v$ stojlax, $v$ doil'ny' $x$ zalax i na ustanovkax dobrovol'nogo doeniya (robotax) . Molochnoe i myasnoe skotovodstvo, 1, 1-5.

Maklaxov, A.V., Abramova, N.N., \& Burgomistrova, O.N. (2016). E`kster`er korov cherno-pestroj porody` na fermax s intensivny`mi texnologiyami. Glavny`j zootexnik, 12, 23-28.

Maklaxov, A.V., Zhil’zov, V.I., \& Nikitin, L.A. (2017). Sravnitel'naya ocenka e`kologicheskoj e`ffektivnosti ispol’zovaniya doil’ny`x robotov v $\mathrm{O}$ «Pokrovskoe» Vologodskoj oblasti. E`konomika i e`kologicheskie nauki, 5, 1-15.

Mironova, T., \& Muromcev, A. (2013). Produktivnost i zabolevaemost' mastitom korov pri ispol’zovanii robotizirovannoj i mashinnoj sistemy doeniya. Molochnoe i myasnoe skotovodstvo, 35, 30-31.

Palii, A.P., Nanka, O.V., \& Prudnikov, V.G. (2019). Preconditions for eco-friendly milk production on the modern dairy complexes. Ukrainian Journal of Ecology, 9, 56-62.

Prudnikov, V.H., Lysenko, H.L., \& Vasylieva, Y.O. (2015). Tekhnolohiia vyrobnytstva yalovychyny. Kharkiv: Stil-Izdat.

Prudnikov, V.H., Tarasova, T.O., \& Tarasov, M.A. (2011). Porivnialna kharakterystyka koriv riznykh porid za bilkovomolochnistiu ta yakistiu syru. Naukovyi visnyk Lvivskoho Natsionalnoho universytetu veterynarnoi medytsyny im. S. Z. Hzhytskoho, 13, 364-371.

Sobol', N. (2008). Roboty`doyary` - na Vologodskoj zemle. Zhivotnovodstvo Rossii, 1, 44-46.

Surovcev, V.N., \& Nikulina, Y.N. (2013). Ocenka e`kologicheskoj e`ffektivnosti innovacionny`x texnologij doeniya i soderzhaniya molochnogo stada. Molochnoe i myasnoe skotovodstvo, 1, 2-5.

Taratorkin, V.M., Samraxanov, T.G., \& Abrashkin, P.A. (2017). Robotizaciya molochnogo skotovodstva 
ustojchivy j trend. E'ffektivnoe zhivotnovodstvo, 1,

9-13.

Timoshenko, V., \& Muzy`ka, A. Chto nuzhno znat`o doil’ny`x robotax . Belorusskoe sel'skoe xozyajstvo. 26.04.2013 Web. 23.01.2019 Retrieved from

http://agriculture.by/articles/zhivotnovodstvo/chtonuzhno-znat-o-doilnyh-robotah

Travecz kij, M. Astarta-Kiev» planiruet robotizirovat' sobstvenny`e fermy`. Milkua.info. 26.12.2018 Web. 18.03.2019 Retrieved from http://milkua.info/ru/post/astarta-kiev-planiruetrobotizirovat-sobstvennye-fermy.

Viniczkij, S., Romanyuk, V., \& Saviny`x, P. (2014). E'ffektivnost' primeneniya doil'ny'x robotov na semejny`x fermax Pol`shi. Agrarnaya nauka EvroSevero-Vostoka, 4, 52-56.

Vinniczkij, S., Romanyuk, V., \& Yugovar, E. (2014). E’ffektivnost' primeneniya doil'ny`x robotov na fermax krupnogo rogatogo skota. Vestnik Marijskogo gosudarstvennogo universiteta, 1, 2835. 